\title{
Percepcja technik wychowawczych rodziców a zadowolenie z życia młodych osób w okresie adolescencji i wczesnej dorosłości
}

\section{Perception of the Parenting Techniques and Satisfaction with Life of Young People in Adolescence and Early Adulthood}

\begin{abstract}
The authors analyze the satisfaction with life of young people in relation to the perception of the parenting techniques. 524 school and university students from the Podkarpacie region aged 13-22 were surveyed using the Inventory of Parental Discipline Techniques (IPDT) by Gała and the Student's Life Satisfaction Scale (SLSS) by Huebner. The dominant technique used by parents is that of introduction to principles. Fathers use the technique of indifference more often than mothers. Mothers use the technique of power assertion more frequently as their children grow in age. Parenting techniques have a significant relationship with the level of life satisfaction of the adolescents and young adults, but at different stages of development different parental techniques are associated with their life satisfaction.
\end{abstract}

Keywords: youth, stages of development, satisfaction with life, parenting techniques

Słowa kluczowe: młodzież, etapy rozwoju, zadowolenie z życia, techniki wychowawcze.

\section{WPROWADZENIE}

Zadowolenie z życia, szczęście, dobrostan psychiczny czy też jakość życia to pojęcia, które coraz częściej pojawiają się nie tylko w życiu przeciętnego człowieka, ale także jako przedmiot intensywnych badań naukowych. I choć o szczęściu ludzkim mówiło się już w starożytności, to dopiero w XX w. zaczęto poszukiwać w sposób naukowy determinantów tego zjawiska.

Satysfakcja życiowa jest pojęciem wielowymiarowym - pokazuje ono stopień, w jakim osoba patrzy pozytywnie na własne życie, jak bardzo podoba się jej życie, które jest jej udziałem (Arrindell, Heesink, Feij, 1999; Czapiński, 1994; Diener, 1984; Wnuk i in., 2013). Ta ocena życia, zadowolenia z niego jako całości może uwzględniać dwa wymiary: afektywny i poznawczy. O aspekcie emocjonalnym mówimy wówczas, kiedy osoba określa stan swoich emocji - ich rodzaj (emocje pozytywne lub negatywne) i poziom (niski vs wysoki). W aspekcie poznawczym osoba ujmuje swoje zadowolenie z życia z perspektywy mniej lub bardziej racjonalnej oceny poszczególnych aspektów swego życia bądź dokonując generalnej oceny życia jako dobrego/złego bądź swoiście bilansując dodatnie i ujemne aspekty życia (Ryff, 1989). Satysfakcja z życia jest czynnikiem, który pozytywnie wiąże się zarówno ze zdrowiem fizycznym, jak i psychicznym, a także z zachowaniami zdrowotnymi (Boniel-Nissim i in., 2014) i jako taka stanowi ważny element funkcjonowania jednostki. 
Nieustanny wzrost zainteresowania zadowoleniem czy satysfakcją z życia, jego jakością i poczuciem szczęścia człowieka znajduje odzwierciedlenie w poszukiwaniu czynników przyczyniających się do odczuwania dobrostanu i jednocześnie zadawania pytań o to, co można zmienić, by doświadczanie zadowolenia z życia było możliwe (Kurpiel, 2015). Satysfakcja z życia okazuje się wypadkową wielu czynników, zarówno środowiskowych, np. charakterystyki systemu rodzinnego (Edwards, Lopez, 2006; Henry, 1994; Wołpiuk-Ochocińska, Marmola, 2016), klimatu organizacyjnego w pracy (Avey, Luthans, Smith, Palmer, 2010), jak i czynników intrapersonalnych, tj.: cech osobowości (np. neurotyzmu czy samooceny) (Diener, Diener, 1995; Peterson, Ruch, Beermann, Park, Seligman, 2007), inteligencji emocjonalnej (Palmer, Donaldson, Stough, 2002) czy orientacji życiowej (Allan, Duffy, 2014; Hofer, Chasiotis, 2003; Peterson, Park, Seligman, 2005).

We wczesnej fazie okresu dojrzewania zachodzą intensywne i liczne zmiany we wszystkich obszarach funkcjonowania jednostki. Dotychczasowe wzorce postępowania, wyniesione z dzieciństwa, przestają być skuteczne, a nowe jeszcze się nie pojawiły. Adolescent doświadcza dysharmonii między oczekiwaniami wobec siebie i otaczającego świata a jego kompetencjami - co z kolei wpływa na jego obraz własnej osoby i związane z nim emocje.

W okresie wczesnej adolescencji istotne znaczenie dla obrazu siebie i relacji z rodzicami mają zmiany biologiczne, które mogą stanowić dla nastolatka zarówno źródło radości, jak i dezaprobaty lub ambiwalencji. Jest to również czas intensywnego poszukiwania własnej tożsamości, który to proces także może powodować niepokój i poczucie zagubienia, a zarazem radość, wiążącą się z poczuciem autonomii. Młody człowiek poszukuje swojej tożsamości przez testowanie niezawodności miłości rodziców lub próby zmieniania siebie przez eksperymentowanie (zmiana trendów, mody itp.) (Obuchowska, 2007). Późna adolescencja jest już okresem dużo spokojniejszym, zmierzającym do uzyskania przez młodego człowieka dojrzałości uczuciowej, cechującej się kontrolą zewnętrznych przejawów uczuć, niezależnoś- cią, opanowaniem i socjocentryzmem. Coraz bardziej autonomiczne myślenie, twórcze podejście do rozwiązywania problemów sprzyjają zakończeniu kryzysu związanego z poszukiwaniem tożsamości i wchodzeniu w dorosłość jako autonomiczna jednostka (Piotrowski, Wojciechowska, Ziółkowska, 2014).

Wczesna dorosłość to z kolei swoisty nowicjat, w trakcie którego jednostka uczy się nie tylko podejmować nowe wyzwania, ale i wywiązywać się z nich (Smykowski, 2004), rozpoczyna budowanie dorosłej struktury życia opartej na motywacji do działania, aktywności i kreatywności (Levinson, 1986). Młodzi stają w obliczu nowych wyzwań i zmian prowadzących do troski o innych i aktywności na rzecz drugiego człowieka. To, jak poradzą sobie z zadaniami wczesnej dorosłości, zależy od sposobu rozwiązania wcześniejszego kryzysu tożsamości. Pozytywne jego rozwiązanie, tzw. tożsamość osiągnięta, sprzyja poczuciu kompetencji w nowych obszarach funkcjonowania i podejmowaniu kolejnych wyzwań, a to z kolei prowadzi do poczucia zadowolenia z życia (Steca, Caprara, Tramontano, Vecchio, Roth, 2009). Również przedłużanie okresu moratorium poza późną adolescencję jest niekorzystne, skutkuje bowiem unikaniem podejmowania wiążących decyzji i odpowiedzialności za nie. Najtrudniej jednak wejść w dorosłość, gdy kryzys tożsamości został rozwiązany przez przyjęcie tożsamości rozproszonej, ponieważ prowadzi to do pomieszania ról i konfliktów na skutek nałożenia zadań późnej adolescencji i wczesnej dorosłości, co nie przynosi satysfakcji, a często staje się źródłem negatywnej oceny społecznej (Ziółkowska, 2005).

W perspektywie rozwoju interesujące wydają się zmiany w zakresie postrzegania własnego życia i zadowolenia z niego. Można zakładać, że koniec okresu adolescencji i osiągnięcie względnej równowagi i dojrzałości w zakresie zmian o charakterze biologicznym, poznawczym i społeczno-emocjonalnym powinno skutkować wyższym poziomem satysfakcji z życia. Względna stabilizacja w okresie wczesnej dorosłości (młodości) powinna tę satysfakcję jeszcze intensyfikować. Wyniki badań jednak w tej mierze nie są jednoznaczne. Dla przykładu 
odnotowano związek między poziomem zadowolenia z życia a wiekiem chłopców i dziewcząt (Goldbeck, Schmitz, Besier, Herschbach, Henrich, 2007), podkreślając, że wraz z wiekiem $\mathrm{u}$ adolescentów zadowolenie z życia się obniża. Badania podłużne nad dobrostanem nastolatków w wieku 12-16 lat pokazały tylko nieznaczny (nieistotny statystycznie) spadek zadowolenia z życia wraz z kolejnymi latami adolescencji (Casas i in., 2007), podczas gdy badania nad zadowoleniem między wczesnym a późnym okresem dojrzewania nie wykazały istotnie znaczących różnic (Al-Attiyah, Nasser, 2013). Podobne wyniki uzyskano w przypadku studentów (Antaramian, Huebner, 2009) w tym wypadku autorzy podkreślają jednak znaczenie kontekstu (kulturowego, rodzinnego) w zrozumieniu natury zadowolenia z życia u adolescentów.

Rodzina jawi się jako istotny czynnik kształtujący zadowolenie z życia człowieka. W przypadku młodych osób elementami mającymi znaczenie dla odczuwanej radości życia wydają się zarówno właściwe relacje z rodzicami, jak i pozytywne stosunki z rodzeństwem. Wcześniejsze badania autorek (Wołpiuk-Ochocińska, Marmola, 2016) wskazują, że na różnych etapach rozwoju młodego człowieka na zadowolenie z życia mają wpływ relacje rodzinne o innym charakterze. Postawy autonomii i spójności rodziców wobec adolescentów i młodych dorosłych okazują się tymi, które odgrywają najbardziej istotną rolę w procesie wychowania. Inne badania potwierdziły np., że matczyne ciepło ma znaczący wkład w przewidywanie przystosowania emocjonalnego u adolescentów, a ciepło ojca znacząco przewiduje późniejsze osiągnięcia społeczne i szkolne. Stwierdzono także, że pobłażliwość ojcowska, ale nie matczyna, w znacznym stopniu przewidywała trudności dostosowawcze dzieci (Chen, Liu, Li, 2000).

\section{Znaczenie rodziny w wychowaniu}

Rodzina stanowi pierwsze i naturalne środowisko, do którego należy dziecko od pierwszych chwil swojego istnienia; na niej spoczywa odpowiedzialność za wychowanie potomstwa, otoczenie go opieką i zapewnienie mu poczucia bezpieczeństwa. Tu dziecko zdobywa podstawowe umiejętności, które będzie wykorzystywać w przyszłym życiu, oraz uczy się odgrywania różnych ról społecznych, zwłaszcza ról rodzinnych. Wychowanie stanowi złożony proces oddziaływań rodziców na dzieci, który najogólniej określić można jako wspieranie w rozwoju (Braun-Gałkowska, 2003). Można je traktować jako świadome wywieranie ukierunkowanego wpływu oraz intencjonalne działania, które pozwolą na osiagnięcie względnie trwałych zmian (Kuncewicz, Sokołowska, 2014). Ponadto, biorąc pod uwage jakość interakcji rodzica z dzieckiem oraz charakterystykę środowiska rodzinnego, wychowanie jest procesem, w którym współuczestniczą dwa podmioty: dziecko i osoba dorosła, podejmując wzajemne działanie na rzecz tworzenia społeczności i ,wrastania w kulturę" (Dryll, 2013). Istotnymi dla tego procesu czynnikami będą obecność i responsywność rodzica, czyli jego adekwatne reagowanie na potrzeby dziecka (Dryll, 2001). Wychowanie ma więc charakter interakcyjny, zakłada bowiem relację $\mathrm{i}$ jest osadzone w jakimś kontekście ideologicznym i kulturowym. Można je ujmować na kontinuum: od kierowania rozwojem drugiego człowieka, poprzez współpracę wychowawcy z wychowankiem, aż do organizowania odpowiednich warunków do rozwoju innym ludziom (Nowak-Dziemianowicz, 2013). Proces ten zmierza do tego, aby wychowanek stał się osobą dojrzałą, a więc samodzielną, twórczą i zorientowaną na wartości (Braun-Gałkowska, 1994).

Środowisko rodzinne w dwojaki sposób oddziałuje na rozwój i kształtowanie osobowości młodego człowieka: albo przez świadomą pracę wychowawczą, albo przez oddziaływania, które mają charakter niezamierzony. Tu istotne wydają się sposoby wzajemnego odnoszenia się do siebie danych członków rodziny, a zwłaszcza stosunek rodziców do dziecka (Ziemska, 1979).

Relacje rodziców z dziećmi, a szczególnie wychowanie, są funkcją rodziny jako dynamicznej całości (Gosztyła, 2010). Rodzinę należy traktować jako grupę osób, które tworzą złożoną strukturę, pozostają we wzajemnej zależności, dzielą wspólną historię, a ponadto łączą je 
emocjonalne więzi (Plopa, Połomski, 2010). Jak każdy system rodzina składa się z hierarchicznie uporządkowanych subsystemów (Drożdżowicz, 1999), które stawiają sobie wspólne cele i zadania (Plopa, 2004). Podkreśla się często, że rodzina jest tym środowiskiem, które najpełniej zaspokaja potrzeby dziecka, jako że zapewnia najlepszą opiekę i najkorzystniejsze warunki rozwoju, a dzięki miłości i poczuciu bezpieczeństwa dziecko czuje się po prostu szczęśliwe (Rembowski, 1972; Filipczuk, 1988; Raczkowska, 1998). Tu kształtują się wzorce postępowania i społeczna osobowość dziecka, tu poznaje ono wartości moralne i uświadamia sobie ich znaczenie, tu uczy się komunikacji, współżycia z innymi ludźmi i życia w zgodności z samym sobą. Tu w końcu dokonują się niepowtarzalne przeżycia i doświadczenia formujące młodego człowieka (Rembierz, 1998).

Wyzwaniem dla rodziców staje się komunikacja z dorastającymi dziećmi, jako że zmianie ulega w tym czasie rodzaj wzajemnych relacji. Zmienia się nie tylko intensywność wzajemnych kontaktów, ale i ich treść, stopień wzajemnego dzielenia się doświadczeniami, postrzeganie prywatności i odpowiedzialności (Plopa, Połomski 2010). Proces dorastania dzieci modyfikuje relacje rodzinne. Wpływ rodziców zaczyna się zmniejszać, co wynika z dążenia nastolatków do swobody i niezależności (Steinberg, Morris, 2001), ale też wiąże się z osłabieniem więzi, spadkiem autorytetu rodziców oraz częstymi konfliktami (Obuchowska, 2007). Zawsze jednak ważna jest dla młodych możliwość obserwowania partnerskiej, otwartej komunikacji między rodzicami lub między rodzicami a nimi, gdyż wówczas uczą się oni komunikować się z innymi również w sposób partnerski, zaś jeśli w domu dominuje niepartnerski styl komunikowania się, to dziecko może przejąć i utrwalić właśnie ten styl porozumiewania się (Grzesiuk, 1979; Harwas-Napierała, 2014).

Osoby, które w świetle prawa osiagnęły pełnoletność, uważają, że już są dorosłe, wielu młodych ludzi doświadcza niestety iluzji, że mogą robić, co im się spodoba, a jednocześnie pozostawać pod ochroną rodzicielską. Stopniowo młodzi dorośli zaczynają kształtować bardziej dojrzałe relacje z rówieśnikami, odnajdują się w kontekście ról związanych ze swoją płcia, przygotowują się do założenia rodziny, a ponadto poznają własne możliwości oraz ich granice, co skutkuje zachowaniami prozdrowotnymi lub destrukcyjnymi (Zadworna-Cieślak, Ogińska-Bulik, 2011; Waldowski, 2002). Osiagają także niezależność emocjonalną, zwłaszcza wobec rodziców lub opiekunów. Ponadto krystalizuje się wówczas ich system etyczny, będący podstawą światopoglądu oraz prowadzący do zachowań zgodnych z tym, co jest ogólnie akceptowane przez otoczenie społeczne (Dobrenko, 2013). Stąd nie potrzebują już tak bardzo dyscyplinowania ze strony innych dorosłych, a jednocześnie mają w pamięci te zachowania rodzicielskie, które wpłynęły na ukształtowanie się ich takimi, jakimi są obecnie.

\section{Techniki wychowawcze}

Techniki wychowawcze określane są jako sposoby dyscyplinowania dzieci przez rodziców. Oznaczają one to, w jaki sposób rodzice starają się zmienić zachowanie dziecka w sytuacji, gdy łamie ono ustalone przez nich zasady, zachowuje się wbrew ich woli (Hoffman, 2006). Należą do nich różne rodzicielskie interwencje, takie jak: napomnienia, wymówki, perswazje, nagrody, kary, zachęty, które stosują rodzice, uznając je za właściwe, aby wpoić dziecku określone standardy zachowania (Gała, 1992).

Istotną rolę w procesie wychowania odgrywa sposób dyscyplinowania dziecka, a więc takie postępowanie rodzica, które stara się zmienić zachowanie dziecka czasami wbrew jego woli. Dyscyplina zdaniem niektórych autorów (Hoffman, 1975) jest ważna, ponieważ umożliwia dzieciom doświadczanie osiagania równowagi między ekspresją i kontrolowaniem własnych pragnień. Techniki dyscyplinujące nie ograniczają się do wąsko rozumianej kary lub nagrody, lecz obejmują wszystko to, co czynią rodzice, aby doprowadzić dziecko do takich standardów zachowania, które oni sami uznają za właściwe.

Zdaniem Hoffmana (1970, 1975, 1994) zachowania rodziców dyscyplinujących swoje dzieci można sprowadzić do trzech technik wychowawczych: 
1. Podkreślanie mocy - technika ta polega na wykorzystywaniu swojej przewagi nad dzieckiem; występuje jako żądania czegoś albo groźby dotyczące możliwości użycia siły fizycznej lub pozbawienia własności i przywilejów, zdarza się, że wiąże się z rzeczywistym użyciem siły lub pozbawieniem dziecka czegoś, co jest dla niego ważne; zmusza dziecko do natychmiastowego posłuszeństwa. Zachowania takie mogą być usprawiedliwione jedynie wtedy, gdy rodzic musi działać, aby uchronić dziecko przed niebezpieczeństwem. Negatywne skutki stosowania tej techniki polegają na tym, że dzieci uczą się, iż można przewagą i władzą zmusić kogoś do zmiany zachowania, i będa one wykorzystywać to wobec rówieśników lub rodzeństwa, a więc osób, które mają nad nimi mniejszą władzę. Ponadto technika ta wywołuje w dziecku gniew i strach; zaburza poczucie autonomii i wolności dziecka, powoduje u dziecka strach przed karą zamiast myślenia o konsekwencjach zachowania; uruchomia zewnętrzny, a nie wewnętrzny system kontroli własnych zachowań. Może prowadzić do unikania kontaktu z rodzicem i zaburzeń w rozwoju empatii u dziecka (Elżanowska, 2012).

2. Wycofywanie miłości - polega na pozbawianiu dziecka dowodów miłości rodzicielskiej przez pewien czas. Może przyjąć formę ignorowania dziecka, odmowy słuchania go, rozmawiania; rodzice mogą też izolować dziecko, grozić, że je zostawią. Jest formą porzucenia dziecka i odseparowania go od rodzica, a więc wykorzystuje więź emocjonalną łączącą rodzica i dziecko i z tego powodu może stanowić dużą karę, szczególnie dla dzieci zależnych. Negatywne skutki stosowania tej techniki to: obawa dziecka o miłość rodzicielską; uczenie dziecka warunkowania miłości i uczuć pozytywnych i jej zależności od poprawnego zachowania; pojawienie się neurotycznego poczucia winy, ponieważ dziecko nie dowiaduje się, dlaczego jego zachowanie jest złe; branie pod uwage jedynie zewnętrznych opinii, a nie wewnętrznych norm przy ocenie przez dziecko swojego postępowania; w dorosłym życiu niechęć do wchodzenia w bliskie relacje emocjonalne z powodu lęku przed odrzuceniem (Gosztyła, 2010; Elżanowska, 2012). Badania wskazują, że brak ciepła ze strony rodziców stanowi predyktor późniejszych problemów o charakterze depresyjnym (por. Hipwell i in., 2008).

3. Wprowadzanie w zasady (indukcja) - polega na wyjaśnianiu dziecku, z jakich powodów jego zachowanie jest niewłaściwe, przez odwoływanie się do konsekwencji zachowań dziecka dla innych oraz pokazywanie wzorów prawidłowych zachowań (Gała, 1992). Niedostosowanie tej techniki do rozwoju poznawczego dziecka i jego możliwości językowych może spowodować niezrozumienie komunikatu rodzica i nie przekona dziecka do jego rozsądnej propozycji. Jednakże zaletą tej techniki jest rozwój empatii u dziecka, uświadamianie jego sprawczej roli i pojawienie się zdrowego poczucia winy z powodu wywołania cierpienia ofiary oraz fakt, że uczy ona altruizmu, dostrzegania potrzeb innych ludzi, oceniania faktów z punktu widzenia drugiej osoby. Częste korzystanie $\mathrm{z}$ tej techniki prowadzi do internalizowania przez dziecko norm i zasad moralnych (Elżanowska, 2012), a w konsekwencji do wyższego poziomu świadomości moralnej (Patrick, Gibbs, 2012). Ponadto technika ta wiąże się z ciepłem rodzicielskim i pozytywną komunikacją w relacji rodzic-dziecko, co w rezultacie prowadzi również do wyższego poziomu zadowolenia z życia u dzieci (Boniel-Nissim i in., 2014; Piko, 2006).

Badania dotyczące technik wychowawczych, prowadzone w Katedrze Psychologii Wychowawczej i Rodziny Katolickiego Uniwersytetu Lubelskiego, ujawniły jeszcze jeden typ zachowania rodziców - brak ich reakcji w sytuacjach, gdy dziecko zachowuje się niewłaściwie, co znaczy, że opiekunowie nie podejmują żadnego działania, aby skorygować zachowanie małoletniego. Również ta technika ma negatywne konsekwencje - gdy dziecko robi to, co chce, nie uczy się powściągania różnych impulsów i w mniejszym stopniu jest zdolne do kontrolowania swoich reakcji (za: Gosztyła, 
2010). Rodzice stosujący tę technikę są niewymagający wobec dziecka - nie interesują się jego zachowaniem, nie wspierają go, nie dostarczają mu wiedzy o normach i zasadach społecznych. Ma to szczególnie złe konsekwencje u dorastających dzieci, powoduje bowiem brak pewności siebie i nieodpowiedzialność w sytuacjach społecznych, a także niższe poczucie szczęścia i mniejszą zdolność do samokontroli (por. Steinberg i in., 1994, za: Elżanowska, 2012).

\section{BADANIA WLASNE}

Celem niniejszego opracowania było znalezienie związków między percepcją technik wychowawczych rodziców przez osoby w wieku adolescencji i wczesnej dorosłości a ich obecnym poczuciem zadowolenia z życia.

\section{Grupa badana}

W badaniach wzięło udział łącznie 524 uczniów i studentów z terenu Podkarpacia. W celu zaobserwowania zmian rozwojowych w po- strzeganiu technik rodzicielskich i poziomie satysfakcji z życia grupę badaną podzielono na 3 podgrupy odpowiadające wiekiem wczesnej adolescencji, późnej adolescencji i wczesnej młodości (por. Brzezińska, 2005). $\mathrm{Na}$ grupę badaną składali się więc uczniowie gimnazjum (gdzie średnia wieku dziewcząt wyniosła $M=14.11, S D=.904$, a chłopców $M=14.29, S D=.903$ ), szkół średnich (średnia wieku dziewcząt $M=16.41, S D=.332$ i chłopców $M=16.25, S D=.455)$ i szkół wyższych (kobiety $M=20.99, S D=1.545$ i mężczyźni $M=21.48, S D=1.663$ ). Nie wystapiły międzypłciowe różnice istotne statystycznie odnośnie do wieku w poszczególnych grupach badanych, a różnice w zakresie wieku były istotne statystycznie na poziomie $p<.000$ między grupami szkolnymi, co jest prawidłowością oczywistą i zamierzoną. Liczebność danych grup przedstawia tabela 1.

W grupie gimnazjalistów proporcja dziewcząt i chłopców była zbliżona. W szkołach średnich (licea ogólnokształcące) i wyższych bardziej liczne były grupy kobiet (odpowiednio $3: 1$ i $2: 1$ ).

Tabela 1. Grupa badana z uwzględnieniem podziału na płeć i miejsce nauki

\begin{tabular}{|l|c|c|c|c|}
\hline & & Kobieta & Mężczyzna & Ogółem badani \\
\hline \multirow{2}{*}{$\begin{array}{l}\text { Gimnazjum } \\
\text { (wczesna adolescencja) }\end{array}$} & $N$ & 84 & 72 & 156 \\
\cline { 2 - 5 } & $\%$ & 16.0 & 13.7 & 29.8 \\
\hline \multirow{2}{*}{$\begin{array}{l}\text { Szkoła średnia } \\
\text { (późna adolescencja) }\end{array}$} & $N$ & 144 & 52 & 196 \\
\hline \multirow{2}{*}{$\begin{array}{l}\text { Szkoła wyższa } \\
\text { (wczesna dorosłość) }\end{array}$} & $\%$ & 27.5 & 9.9 & 37.4 \\
\hline \multirow{2}{*}{ Ogółem } & $N$ & 114 & 58 & 172 \\
\cline { 2 - 5 } & $N$ & 21.8 & 11.1 & 32.8 \\
\cline { 2 - 5 } & $\%$ & 342 & 182 & 524 \\
\hline
\end{tabular}

Źródło: opracowanie własne.

\section{Procedura badania}

Uczestnicy zostali poproszeni o samodzielnie wypełnienie kwestionariuszy opisanych poniżej i przekazano im informacje o warunkach i procedurze badania. Gimnazjaliści i uczniowie szkół średnich wypełniali kwestionariusze w czasie zajęć szkolnych, a studenci podczas zajęć na uczelni. Badanie było anonimowe. Uczestnicy udzielili świadomej zgody na udział w badaniu (w wypadku osób niepełnoletnich zgody udzielili rodzice badanych). 


\section{Narzędzia badawcze}

W badaniach zastosowano następujące narzędzia badawcze:

- Inwentarz Rodzicielskich Technik Wychowawczych IRTW A. Gały (1992),

- Skala SLSS (Student's Life Satisfaction Scale) E. Huebnera (1991).

Inwentarz IRTW autorstwa A. Gały (1992) składa się z 16 itemów. Każdy item zawiera 2 elementy: opis wykroczenia dziecka oraz cztery opisy reakcji rodziców na to wykroczenie (każdy przyporządkowany jednemu typowi technik wychowawczych). Narzędzie jest przeznaczone do badania młodzieży i młodych dorosłych począwszy od okresu dorastania. Badany ma odpowiedzieć retrospektywnie, jakie techniki wychowawcze stosowali rodzice wobec niego w okresie dorastania. Każdy zakreślony opis sygnuje się jednym punktem w zakresie tej techniki, do której jest przyporządkowany (podkreślanie mocy, wprowadzanie w zasady, wycofywanie miłości, obojętność) w przypadku każdego z rodziców. Rzetelność skali w badaniach autorek mierzona testem alfa Cronbacha wynosiła .840 .

Skala SLSS (Student's Life Satisfaction Scale) do badania satysfakcji z życia (Huebner, Suldo, Valois, 2003; Huebner, 1991) jest narzędziem typu self - reportem składającym się z siedmiu pytań. Na skali sześciostopniowej (0-5 pkt) osoby badane oceniaja, w jakim stopniu zgadzają się z podanymi stwierdzeniami - od zdecydowanie nie zgadzam się do zdecydowanie zgadzam się. W badaniach autorek rzetelność polskiej adaptacji mierzona alfą Cronbacha wynosiła .825 dla grupy gimnazjalistów, .847 w odniesieniu do uczniów szkół średnich i .837 dla studentów, co świadczy o dobrej spójności skali. Analiza czynnikowa potwierdziła jednoczynnikową strukturę skali SLSS.

\section{Hipotezy}

Na podstawie analizy dotychczasowych badań autorki postawiły następujące hipotezy badawcze:

a) etap rozwojowy różnicuje poziom satysfakcji z życia badanych osób, b) poziom satysfakcji dzieci i młodzieży ma związek z percepcją technik wychowawczych stosowanych w okresie dorastania przez ich rodziców - technika pozytywna wprowadzania w zasady podnosi poziom zadowolenia z życia, a techniki negatywne (wycofywania miłości, podkreślania mocy i obojętności) obniżają poziom satysfakcji z życia.

\section{WYNIKI}

W przedstawionej poniżej analizie statystycznej uwzględniono trzy grupy wieku odpowiadające poszczególnym fazom rozwojowym z uwzględnieniem etapu nauki badanych: uczniów ze szkół gimnazjalnych (wczesna adolescencja), uczniów ze szkół średnich (późna adolescencja) i studentów szkół wyższych (wczesna dorosłość). W poszczególnych grupach badanych porównano dziewczęta i chłopców w zakresie postrzeganych przez nich technik wychowawczych stosowanych przez ich rodziców. Wyniki przedstawiają tabele 2-4.

W opinii badanych gimnazjalistów ich rodzice najczęściej stosują technikę wprowadzania w zasady, najrzadziej natomiast technikę związaną z obojętnością. Jednocześnie dziewczęta oceniają, że ich matki i ojcowie częściej podkreślają swoją przewagę wobec nich w porównaniu z chłopcami. W zakresie pozostałych technik nie pojawiają się różnice w traktowaniu między dziewczętami i chłopcami.

Zauważalne są jednakże różnice w nasileniu poszczególnych technik między matkami i ojcami w stosunku do swoich dzieci. Okazuje się, że matki istotnie częściej $(d=.208, p<.000)$ wykorzystuja technikę wprowadzania w zasady w porównaniu z ojcami, a ojcowie istotnie częściej $(d=-.341, p<.000)$ stosują technikę obojętności. W zakresie techniki podkreślania mocy i wycofywania miłości nie pojawiają się różnice istotne statystycznie.

Także w grupie uczniów szkół średnich rodzice najczęściej stosują technikę wprowadzania w zasady. Najmniej popularną techniką wśród matek licealistów jest obojętność, a wśród ojców - wycofywanie miłości. Rodzice w sposób jednakowy traktują swoje córki i synów - 
Tabela 2. Różnice w postrzeganiu stosowanych przez rodziców technik wychowawczych u gimnazjalistów obu płci

\begin{tabular}{|c|c|c|c|c|c|c|}
\hline \multicolumn{2}{|l|}{ Gimnazjum } & $N$ & Średnia & $\begin{array}{c}\text { Odchylenie } \\
\text { standardowe }\end{array}$ & $t / U$ & Istotność \\
\hline \multirow{2}{*}{ Matka - podkreślanie mocy } & $K$ & 84 & 4.63 & 4.649 & \multirow{2}{*}{2.447} & \multirow{2}{*}{$\begin{array}{c}.016 \\
(d=.396)\end{array}$} \\
\hline & $M$ & 72 & 3.01 & 3.384 & & \\
\hline \multirow{2}{*}{ Matka - wycofywanie miłości } & $K$ & 84 & 1.75 & 2.167 & \multirow{2}{*}{.205} & \multirow{2}{*}{.836} \\
\hline & $M$ & 72 & 1.68 & 2.041 & & \\
\hline \multirow{2}{*}{$\begin{array}{l}\text { Matka - wprowadzanie } \\
\text { w zasady }\end{array}$} & $K$ & 84 & 7.26 & 5.477 & \multirow{2}{*}{1.368} & \multirow{2}{*}{.173} \\
\hline & $M$ & 72 & 6.07 & 5.366 & & \\
\hline \multirow{2}{*}{ Matka - obojętność } & $K$ & 84 & .83 & 1.574 & \multirow{2}{*}{$-1,357$} & \multirow{2}{*}{.177} \\
\hline & $M$ & 72 & 1.25 & 2.244 & & \\
\hline \multirow{2}{*}{ Ojciec - podkreślanie mocy } & $K$ & 84 & 4.60 & 4.610 & \multirow{2}{*}{2.884} & \multirow{2}{*}{$\begin{array}{c}.004 \\
(d=.468)\end{array}$} \\
\hline & $M$ & 72 & 2.72 & 3.260 & & \\
\hline \multirow{2}{*}{ Ojciec - wycofywanie miłości } & $K$ & 84 & 1.76 & 2.016 & \multirow{2}{*}{-.231} & \multirow{2}{*}{.817} \\
\hline & $M$ & 72 & 1.83 & 1.808 & & \\
\hline \multirow{2}{*}{$\begin{array}{l}\text { Ojciec - wprowadzanie } \\
\text { w zasady }\end{array}$} & $K$ & 84 & 5.85 & 5.231 & \multirow{2}{*}{.617} & \multirow{2}{*}{.538} \\
\hline & $M$ & 72 & 5.33 & 5.091 & & \\
\hline \multirow{2}{*}{ Ojciec - obojętność } & $K$ & 84 & 1.48 & 2.284 & \multirow{2}{*}{-1.747} & \multirow{2}{*}{.083} \\
\hline & $M$ & 72 & 2.21 & 2.945 & & \\
\hline
\end{tabular}

Źródło: opracowanie własne.

Tabela 3. Różnice w postrzeganiu stosowanych przez rodziców technik wychowawczych u uczniów szkół średnich obu płci

\begin{tabular}{|c|c|c|c|c|c|c|}
\hline \multicolumn{2}{|l|}{ Szkoła średnia } & $N$ & Średnia & $\begin{array}{l}\text { Odchylenie } \\
\text { standardowe }\end{array}$ & $t / U$ & $\begin{array}{c}\text { Istotność } \\
\text { (dwustronna) }\end{array}$ \\
\hline \multirow{2}{*}{ Matka - podkreślanie mocy } & $K$ & 144 & 3.24 & 3.345 & \multirow{2}{*}{-.446} & \multirow{2}{*}{.656} \\
\hline & $M$ & 52 & 3.48 & 3.134 & & \\
\hline \multirow{2}{*}{ Matka - wycofywanie miłości } & $K$ & 144 & 1.40 & 1.747 & \multirow{2}{*}{-.477} & \multirow{2}{*}{.635} \\
\hline & $M$ & 52 & 1.54 & 1.883 & & \\
\hline \multirow{2}{*}{$\begin{array}{l}\text { Matka - wprowadzanie } \\
\text { w zasady }\end{array}$} & $K$ & 144 & 6.26 & 5.163 & \multirow{2}{*}{.654} & \multirow{2}{*}{.517} \\
\hline & $M$ & 52 & 5.73 & 4.670 & & \\
\hline \multirow{2}{*}{ Matka - obojętnośćć } & $\mathrm{K}$ & 144 & .94 & 1.794 & \multirow{2}{*}{.263} & \multirow{2}{*}{.793} \\
\hline & $M$ & 52 & .87 & 1.372 & & \\
\hline \multirow{2}{*}{ Ojciec - podkreślanie mocy } & $K$ & 144 & 2.84 & 3.126 & \multirow{2}{*}{.623} & \multirow{2}{*}{.534} \\
\hline & M & 52 & 2.54 & 2.601 & & \\
\hline \multirow{2}{*}{ Ojciec - wycofywanie miłości } & $K$ & 144 & 1.22 & 1.561 & \multirow{2}{*}{-.213} & \multirow{2}{*}{.832} \\
\hline & $M$ & 52 & 1.27 & 1.586 & & \\
\hline \multirow{2}{*}{$\begin{array}{l}\text { Ojciec - wprowadzanie } \\
\text { w zasady }\end{array}$} & $K$ & 144 & 5.27 & 4.938 & \multirow{2}{*}{.125} & \multirow{2}{*}{.901} \\
\hline & $M$ & 52 & 5.17 & 4.545 & & \\
\hline \multirow{2}{*}{ Ojciec-obojętność } & $K$ & 144 & 1.78 & 2.804 & \multirow{2}{*}{-1.232} & \multirow{2}{*}{.220} \\
\hline & $M$ & 52 & 2.37 & 3.206 & & \\
\hline
\end{tabular}

Źródło: opracowanie własne. 
Tabela 4. Różnice w postrzeganiu stosowanych przez rodziców technik wychowawczych u studentów obojga płci

\begin{tabular}{|c|c|c|c|c|c|c|}
\hline \multicolumn{2}{|l|}{ Szkoła wyższa } & $N$ & Średnia & $\begin{array}{l}\text { Odchylenie } \\
\text { standardowe }\end{array}$ & $t / U$ & $\begin{array}{c}\text { Istotność } \\
\text { (dwustronna) }\end{array}$ \\
\hline \multirow{2}{*}{ Matka - podkreślanie mocy } & $K$ & 114 & 3.80 & 3.273 & \multirow{2}{*}{.821} & \multirow{2}{*}{.413} \\
\hline & $M$ & 58 & 3.36 & 3.339 & & \\
\hline \multirow{2}{*}{ Matka - wycofywanie miłości } & $K$ & 114 & 2.14 & 2.116 & \multirow{2}{*}{-.440} & \multirow{2}{*}{.661} \\
\hline & $M$ & 58 & 2.29 & 2.224 & & \\
\hline \multirow{2}{*}{$\begin{array}{l}\text { Matka - wprowadzanie } \\
\text { w zasady }\end{array}$} & $K$ & 114 & 7.55 & 4.388 & \multirow{2}{*}{.911} & \multirow{2}{*}{.363} \\
\hline & $M$ & 58 & 6.90 & 4.610 & & \\
\hline \multirow{2}{*}{ Matka - obojętność } & $K$ & 114 & 1.21 & 1.975 & \multirow{2}{*}{-.383} & \multirow{2}{*}{.702} \\
\hline & $M$ & 58 & 1.33 & 1.721 & & \\
\hline \multirow{2}{*}{ Ojciec - podkreślanie mocy } & $\mathrm{K}$ & 114 & 3.12 & 3.185 & \multirow{2}{*}{-.161} & \multirow{2}{*}{.872} \\
\hline & $M$ & 58 & 3.21 & 3.355 & & \\
\hline \multirow{2}{*}{ Ojciec - wycofywanie miłości } & $K$ & 114 & 1.89 & 1.963 & \multirow{2}{*}{.173} & \multirow{2}{*}{.863} \\
\hline & M & 58 & 1.83 & 2.318 & & \\
\hline \multirow{2}{*}{$\begin{array}{l}\text { Ojciec - wprowadzanie } \\
\text { w zasady }\end{array}$} & $K$ & 114 & 5.95 & 4.358 & \multirow{2}{*}{.093} & \multirow{2}{*}{.926} \\
\hline & $M$ & 58 & 5.88 & 4.878 & & \\
\hline \multirow{2}{*}{ Ojciec-obojętność } & $K$ & 114 & 3.20 & 3.548 & \multirow{2}{*}{.473} & \multirow{2}{*}{.637} \\
\hline & $M$ & 58 & 2.93 & 3.553 & & \\
\hline
\end{tabular}

Źródło: opracowanie własne.

w tym zakresie nie pojawiły się różnice istotne statystycznie.

Zauważalne są natomiast różnice w nasileniu poszczególnych technik między matkami i ojcami w stosunku do swoich dzieci. Okazuje się, że matki istotnie częściej stosują technikę wprowadzania w zasady $(d=.179, p<.000)$ i podkreślania mocy $(d=.176, p=.006) \mathrm{w}$ porównaniu z ojcami, a ojcowie istotnie częściej $(d=-.429, p<.000)$ stosują technikę obojętności. W zakresie techniki wycofywania miłości nie pojawiają się różnice istotne statystycznie.

Średnie wyniki badanych studentów wskazują, że w działaniach matek i ojców dominuje technika wprowadzania w zasady, która traktowana jest jednocześnie jako najbardziej efektywna w wychowaniu. Matki najrzadziej stosuja techniki związane z obojętnością, a ojcowie najrzadziej wycofują swoją miłość. Okazuje się, że w stosunku do studentek i studentów rodzice podobnie wykorzystują wszystkie tech- niki wychowawcze - nie stwierdzono różnic istotnych statystycznie w tym zakresie między uczniami i uczennicami, co przedstawia tabela 4. Zauważalne są natomiast różnice między matkami i ojcami w nasileniu poszczególnych technik wychowawczych. Matki studentów istotnie częściej w porównaniu z ojcami stosują technikę podkreślania mocy $(d=.154, p=.049)$, wprowadzania w zasady $(d=.315, p<.000)$ i wycofywania miłości $(d=.152, p=.042)$, a ojcowie istotnie częściej $(d=-.657, p<.000)$ stosują technikę obojętności.

Przedstawione w tabeli 5 wyniki średnie dla poszczególnych grup sugerują przeciętny poziom satysfakcji z życia badanej młodzieży (Huebner, 1991). Co ciekawe, wraz ze wzrostem poziomu edukacji (a tym samym wieku i poziomu dojrzałości badanych) zadowolenie z obecnego życia jest wyższe, nie są to jednak różnice istotne na poziomie statystycznym $(p>.05)$. Badani uczniowie zarówno z gimnazjum, jak 
i ze szkoły średniej oraz studenci doceniają to, co posiadają, i to, co ich spotyka.

Okazuje się, że poziom satysfakcji z życia wiąże się ze sposobem, w jaki rodzice wychowują swoje dzieci. Analiza korelacyjna przedstawiona w tabelach 6-8 wskazuje, że na różnych etapach rozwoju inne techniki wychowawcze rodziców mają znaczenie dla ogólnej satysfakcji życiowej dzieci obojga płci.
W grupie gimnazjalistek analiza korelacyjna wykazała istotny ujemny (słaby bądź umiarkowany) związek między zadowoleniem życiowym a obojętnością ojca i matki i wycofywaniem miłości przez matkę. W przypadku gimnazjalistów natomiast pozytywnie (na poziomie istotnie statystycznym) z zadowoleniem z życia wiąże się technika wprowadzania w zasady przez matkę.

Tabela 5. Poziom zadowolenia z życia badanych uczniów z różnych szkół

\begin{tabular}{|l|c|c|c|}
\hline \multicolumn{1}{|c|}{ Szkoła } & $\boldsymbol{N}$ & Średnia & Odchylenie standardowe \\
\hline Gimnazjum & 147 & 23.20 & 7.692 \\
\hline Szkoła średnia & 192 & 23.94 & 7.192 \\
\hline Szkoła wyższa & 172 & 24.56 & 6.306 \\
\hline Ogółem & 511 & 23.94 & 7.066 \\
\hline \multicolumn{3}{|c|}{ Anova: $F=1.484, p=.227$} \\
\hline
\end{tabular}

Źródło: opracowanie własne.

Tabela 6. Korelacje wyników uzyskanych w badaniu percepcji technik wychowawczych rodziców i ogólnej satysfakcji z życia w okresie wczesnej adolescencji (gimnazja) z podziałem na płeć

\begin{tabular}{|c|c|c|c|}
\hline \multicolumn{4}{|c|}{ Ogólna satysfakcja z życia } \\
\hline \multicolumn{2}{|c|}{ Gimnazjum } & Kobieta & Mężczyzna \\
\hline \multirow{2}{*}{ Matka - podkreślanie mocy } & $r$ & .040 & -.121 \\
\hline & $p$ & .729 & .327 \\
\hline \multirow{2}{*}{ Matka - wycofywanie miłości } & $r$ & $-.287^{*}$ & -.048 \\
\hline & $p$ & .010 & .697 \\
\hline \multirow{2}{*}{ Matka - wprowadzanie w zasady } & $r$ & .124 & $.250^{*}$ \\
\hline & $p$ & .275 & .040 \\
\hline \multirow{2}{*}{ Matka - obojętność } & $r$ & $-.356^{* *}$ & .058 \\
\hline & $p$ & .001 & .637 \\
\hline \multirow{2}{*}{ Ojciec - podkreślanie mocy } & $r$ & -.046 & .073 \\
\hline & $p$ & .690 & .554 \\
\hline \multirow{2}{*}{ Ojciec - wycofywanie miłości } & $r$ & -.072 & -.104 \\
\hline & $p$ & .528 & .398 \\
\hline \multirow{2}{*}{ Ojciec - wprowadzanie w zasady } & $r$ & $.308^{* * *}$ & .119 \\
\hline & $p$ & .006 & .332 \\
\hline \multirow{2}{*}{ Ojciec-obojętność } & $r$ & $-.495^{* *}$ & -.019 \\
\hline & $p$ & .000 & .879 \\
\hline
\end{tabular}

Źródło: opracowanie własne. 
Tabela 7. Korelacje wyników uzyskanych w badaniu percepcji technik wychowawczych rodziców i ogólnej satysfakcji z życia w okresie późnej adolescencji z podziałem na płeć

\begin{tabular}{|c|c|c|c|}
\hline \multicolumn{4}{|c|}{ Ogólna satysfakcja z życia } \\
\hline \multicolumn{2}{|c|}{ Szkoła średnia } & Kobieta & Mężczyzna \\
\hline \multirow{2}{*}{ Matka - podkreślanie mocy } & $r$ & -.097 & .018 \\
\hline & $p$ & .257 & .897 \\
\hline \multirow{2}{*}{ Matka - wycofywanie miłości } & $r$ & -.032 & $-.274^{*}$ \\
\hline & $p$ & .709 & .050 \\
\hline \multirow{2}{*}{ Matka - wprowadzanie w zasady } & $r$ & $.278^{* *}$ & .238 \\
\hline & $p$ & .001 & .089 \\
\hline \multirow{2}{*}{ Matka - obojętność } & $r$ & -.007 & .033 \\
\hline & $p$ & .930 & .818 \\
\hline \multirow{2}{*}{ Ojciec-podkreślanie mocy } & $r$ & .046 & .068 \\
\hline & $p$ & .593 & .633 \\
\hline \multirow{2}{*}{ Ojciec - wycofywanie miłości } & $r$ & -.049 & -.113 \\
\hline & $p$ & .566 & .425 \\
\hline \multirow{2}{*}{ Ojciec - wprowadzanie w zasady } & $r$ & .164 & .259 \\
\hline & $p$ & .052 & .063 \\
\hline \multirow{2}{*}{ Ojciec - obojętność } & $r$ & -.011 & -.173 \\
\hline & $p$ & .901 & .220 \\
\hline
\end{tabular}

Źródło: opracowanie własne.

Tabela 8. Korelacje wyników uzyskanych w badaniu percepcji technik wychowawczych rodziców i ogólnej satysfakcji z życia w okresie wczesnej dorosłości (studenci) z podziałem na płeć

\begin{tabular}{|c|c|c|c|}
\hline \multicolumn{4}{|c|}{ Ogólna satysfakcja z życia } \\
\hline \multicolumn{2}{|c|}{ Szkoły wyższe } & Kobieta & Mężczyzna \\
\hline \multirow{2}{*}{ Matka - podkreślanie Mocy } & $r$ & -.014 & $-.298^{*}$ \\
\hline & $p$ & .886 & .023 \\
\hline \multirow{2}{*}{ Matka - wycofywanie miłości } & $r$ & -.059 & -.103 \\
\hline & $p$ & .530 & .440 \\
\hline \multirow{2}{*}{ Matka - wprowadzanie w zasady } & $r$ & -.034 & .157 \\
\hline & $p$ & .722 & .240 \\
\hline \multirow{2}{*}{ Matka - obojętność } & $r$ & -.004 & -.238 \\
\hline & $p$ & .963 & .072 \\
\hline \multirow{2}{*}{ Ojciec - podkreślanie mocy } & $r$ & -.109 & $-.315^{*}$ \\
\hline & $p$ & .249 & .016 \\
\hline \multirow{2}{*}{ Ojciec - wycofywanie miłości } & $r$ & .027 & -.132 \\
\hline & $p$ & .777 & .323 \\
\hline \multirow{2}{*}{ Ojciec - wprowadzanie w zasady } & $r$ & .132 & $.294^{*}$ \\
\hline & $p$ & .160 & .025 \\
\hline \multirow{2}{*}{ Ojciec - obojętność } & $r$ & -.087 & -.167 \\
\hline & $p$ & .356 & .211 \\
\hline
\end{tabular}

Źródło: opracowanie własne. 
W wypadku uczennic ze szkół średnich poziom satysfakcji z życia determinuje pozytywnie wprowadzenie w zasady przez matki. W grupie uczniów szkół średnich wycofywanie miłości przez matkę decyduje o niższym poziomie ogólnej satysfakcji dziecka.

W grupie studentek ze szkół wyższych na podstawie analizy regresji nie znaleziono korelatów zadowolenia z życia w aspekcie technik wychowawczych stosowanych przez rodziców. U studentów technika wychowawcza ojca i matki w postaci podkreślania mocy negatywnie wpływa na poziom zadowolenia z życia. Okazuje się, że dla zadowolenia w tej grupie istotne jest, aby ojciec traktował dzieci po partnerskubez okazywania przewagi fizycznej, emocjonalnej czy intelektualnej wprowadzał w zasady.

\section{DYSKUSJA}

Satysfakcja z życia jest ważnym i niezbędnym elementem, który przyczynia się do ogólnego poczucia dobrostanu człowieka, wyrażana jest jako reakcja emocjonalna i stosunek jednostki do życia (Diener, Suh, Lucas, Smith, 1999). W wypadku badanych adolescentów i młodych dorosłych poziom satysfakcji z życia okazał się przeciętny. Znajduje to potwierdzenie w badaniach które wykazały, że większość nastolatków pozytywnie ocenia swoje życie (Gilman, Huebner, 2006). Poziom satysfakcji z życia nie różnicował jednak na poziomie statystycznie istotnym badanych grup. Tym samym hipoteza pierwsza nie potwierdziła się. Oczekiwanie, że koniec adolescencji wiążący się z uzyskaniem względnej równowagi życiowej skutkował będzie większym zadowoleniem, nie potwierdziło się - okazuje się, że realizacja wyzwań związanych z jednym zadaniem życiowym prowadzi do konieczności zmierzenia się z kolejnym. Zarówno okres adolescencji, jak i wczesnej dorosłości wymagają nieustannego przystosowywania się do nowych zadań rozwojowych, wiążących się z kryzysowymi przeżyciami i doświadczeniami, więc poziom satysfakcji z życia w tych grupach może być podobny.

Przedstawione analizy pokazują, że najpopularniejszą techniką stosowaną przez rodziców wobec badanych osób, we wszystkich grupach badanych, okazała się technika wprowadzenia w zasady (por. Cichy-Jasiocha, 2017; Marzec-Tarasińska, 2016). Polega ona na wyjaśnianiu dziecku, dlaczego jego zachowanie jest niewłaściwe, głównie przez uświadomienie mu konsekwencji jego zachowania dla innych oraz ukazywanie wzorów właściwego, zgodnego z obowiązującymi zasadami postępowania. Jest to, jak wskazuje Hoffman (1970, 1994), najskuteczniejsza technika dyscyplinująca.

Wyniki badań wskazująjednakże, iż nie ma zgodności w stosowaniu tej techniki między rodzicami. Częściej stosująją matki, szczególnie w odniesieniu do młodszych dzieci, ojcowie zaś częściej niż matki prezentują obojętność i to w odniesieniu do dzieci w każdym wieku. Można więc przypuszczać, że podział ról w zakresie wychowania dzieci w badanych rodzinach jest dość tradycyjny i właśnie na matkach spoczywa główny obowiązek wychowania potomstwa, ojcowie zaś znacznie częściej niż matki pozostają w tych sprawach bierni (Marks, Lam, McHale, 2009; Pankowska, 2005).

Interesujące jest to, że wraz z dojrzewaniem dzieci ich matki częściej stosują technikę okazywania mocy (zwłaszcza wobec dziewcząt), która powoduje zagrożenie własnej autonomii i godności u dziecka, a także rodzi jego wrogość wobec rodzica. Polega ona na demonstrowaniu siły przez matki, gdy nie akceptują zachowań swych dzieci. Można przypuszczać, że stosowanie tej techniki jest wyrazem bezsilności matek - być może nie radzą sobie one skutecznie ze starszymi adolescentami, stosując dotychczasowe techniki. Prawdopodobnie nie uzyskują też wystarczającego wsparcia od swoich mężów, ponieważ ci pozostają częściej obojętni wobec niewłaściwych zachowań dzieci. Rodzi się tu jednak niebezpieczeństwo, że dorastający będą traktować normy i zasady jako narzucone i respektować je tylko z obawy przed ukaraniem.

Przypuszczenie, że techniki wychowawcze mają związek z poziomem satysfakcji z życia, okazało się trafne. Przedstawiona powyżej analiza wyników pozwala stwierdzić istnienie odwrotnej zależności między obojętnością ze strony ojca i wycofywaniem miłości ze 
strony matki a zadowoleniem z życia u córek. Nasuwa się więc wniosek, że techniki te nie tylko słabo dyscyplinują dorastające dzieci, ale także niekorzystnie wpływają na ich zadowolenie z życia. Szczególnie ryzykowne może być wycofywanie miłości, jako że wpływa na poczucie bezpieczeństwa młodego człowieka i może się stać źródłem neurotycznego poczucia winy. Z kolei związek niereagowania na wykroczenia ze strony ojca może powodować poczucie osamotnienia u matek, które starają się wpływać na zachowania dzieci, a w percepcji dziecka, brak konsekwencji w oddziaływaniach matki i ojca.

W grupie badanych uczennic szkół średnich pojawiła się zależność między ich zadowoleniem z życia a stosowaniem techniki wprowadzanie w zasady przez matki. Potwierdza ona, iż własny przykład oraz tłumaczenie dziecku obowiązujących zasad dają najlepsze efekty wychowawcze, zwłaszcza w dłuższej perspektywie, i owocują większym poczuciem zadowolenia z życia. Wcześniejsze badania bowiem pokazały, że wsparcie rodziców w zakresie autonomii dzieci i nadzoru rodzicielskiego nad dziećmi jest istotnie związane $\mathrm{z}$ wyższym poziomem zadowolenia z życia (Argyle, 1987; Diener, 1984).

Trochę inaczej kształtują się zależności uzyskane w badaniu chłopców. Tu zadowolenie z życia gimnazjalistów ma związek z wprowadzaniem w zasady przez matki; dla licealistów brak wycofywania miłości ze strony matek, a dla studentów brak okazywania mocy ze strony oj- ców. Ta odwrotna zależność między zadowoleniem z życia a techniką podkreślania mocy u studentów wydaje się kwestią oczywista, która ma odzwierciedlenie we wcześniejszych badaniach (Kurpiel, 2015). Relacje rodziców z prawie dorosłymi dziećmi nie mogą się opierać na autorytecie siły i zmuszaniu do oczekiwanych zachowań. Młody człowiek podejmuje własne decyzje, a oparcie rodziców jest mu potrzebne w trudnych sytuacjach, w których młodym brakuje doświadczenia. Wtedy konieczne są wsparcie i troska, a nie dowodzenie swoich racji przez rodzica.

\section{WNIOSKI}

Techniki wychowawcze rodziców mają istotny związek z poziomem zadowolenia z życia badanych młodzieży i młodych dorosłych, z tym, że na różnych etapach rozwoju inne techniki wychowawcze wiążą się z zadowoleniem. Aby wychować szczęśliwego syna, we wczesnej adolescencji matka musi mu thumaczyć i dawać przykład respektowania ważnych zasad, ewentualnie pozwolić mu doświadczyć konsekwencji własnych decyzji; w później adolescencji powstrzymać się od emocjonalnego szantażu i komunikatów o miłości warunkowej, a dla młodego dorosłego jeszcze większego znaczenia nabiera miłość i zaufanie ze strony ojca, więc stawianie na swoim, pokazywanie własnej wyższości staje się wtedy ryzykowne (Marzec-Tarasińska, 2016).

\section{BIBLIOGRAFIA}

Al-Attiyah A., Nasser R. (2013), Gender and age differences in life satisfaction within a sex-segregated society: sampling youth in Qatar. International Journal of Adolescence and Youth, 21(1), 84-95.

Allan B.A., Duffy R.D. (2014), Calling, goals, and life satisfaction: A moderated mediation model. Journal of Career Assessment, 22, 3, 451-464.

Antaramian S., Huebner E. (2009), Stability of adolescents' multidimensional life satisfaction report. Journal of Psycho Educational Assessment, 27, 421-425.

Argyle M. (1987), The Psychology of Happiness. London: Methuen.

Arrindell W.A., Heesink J., Feij J. (1999), The Satisfaction with Life Scale (SWLS): Appraisal with 1700 healthy young adults in The Netherlands. Personality and Individual Differences, 26, 5, 815-826.

Avey J.B., Luthans F., Smith R.M., Palmer N.F. (2010), Impact of positive psychological capital on employee well-being over time. Journal of Occupational Health Psychology, 15, 1, 17-28. 
Boniel-Nissim M., Tabak I., Mazur J., Borraccino A., Brooks F., Gommans R., ... Finne, E. (2014), Supportive communication with parents moderates the negative effects of electronic media use on life satisfaction during adolescence. International Journal of Public Health, 60, 2, 189-198.

Braun-Gałkowska M. (1994), W tę samq stronę. Ksiażka dla nauczycieli o wychowaniu i lekcjach wychowawczych. Warszawa: Wydawnictwo Krupski i S-ka.

Braun-Gałkowska M. (2003), Wychowanie i dialog z młodymi. W: S. Koperek, S. Szczur (red.), Servo Veritatis. Materiaty międzynarodowej Konferencji dla uczczenia 25-lecia pontyfikatu Jego Światobliwości Jana Pawła II, 479-490. Kraków: Wydawnictwo Naukowe PAT.

Brzezińska A. (2005), Jak myślimy o rozwoju człowieka. W: A. Brzezińska (red.), Portrety psychologiczne człowieka, 5-20. Gdańsk: GWP.

Casas F., Figuer C., González M., Malo S., Alsinet C., Subarroca S. (2007), The well-being of 12- to 16-yearold adolescents and their parents: Results from 1999 to 2003 Spanish Samples. Social Indicators Research, 83, 87-115.

Chen X., Liu M., Li D. (2000), Parental warmth, control, and indulgence and their relations to adjustment in Chinese children: A longitudinal study. Journal of Family Psychology, 14, 3, 401-419.

Cichy-Jasiocha B. (2017), Techniki wychowawcze rodziców a nadzieja na sukces u młodzieży w okresie późnej adolescencji. W: D. Opozda, M. Leśniak (red.), Rodzicielstwo w wybranych zagadnieniach pedagogicznych, 63-74. Lublin: Episteme.

Czapiński J. (1994), Psychologia szczęścia. Warszawa: PTP.

Diener E. (1984), Subjective well-being. Psychological Bulletin, 95, 3, 542-575.

Diener E., Diener M. (1995), Cross-cultural correlates of life satisfaction and self-esteem. Journal of Personality and Social Psychology, 68, 4, 653-663, http://doi.org/10.1037/0022-3514.68.4.653.

Diener E., Suh E.M., Lucas R.E., Smith H.L. (1999), Subjective well-being: Three decades of progress. Psychological Bulletin, 125, 2, 276-302.

Dobrenko K. (2013), Adolescencja jako czas przejmowania inicjatywy za własny rozwój. W: E. Sokołowska (red.), Psychologia ksztatcenia i wspierania rozwoju, 146-166. Warszawa: Wydawnictwo Akademii Pedagogiki Specjalnej.

Drożdżowicz L. (1999), Ogólna teoria systemów. W: B. de Barbaro (red.), Wprowadzenie do systemowego rozumienia rodziny, 9-17. Kraków: Wydawnictwo Uniwersytetu Jagiellońskiego.

Dryll E. (2001), Interakcja wychowawcza. Warszawa: Wydawnictwo Instytutu Psychologii PAN.

Dryll E. (2013), Wrastanie w kulturę. Transmisja narracji w wychowaniu rodzinnym. Wydawnictwo: Eneteia, Wydawnictwo Psychologii i Kultury.

Edwards L.M., Lopez S.J. (2006), Perceived family support, acculturation, and life satisfaction in mexican american youth: A mixed-methods exploration. Journal of Counseling Psychology, 53, 3, 279-287.

Elżanowska H. (2012), Znaczenie rodzicielskich technik wychowawczych w rozwoju postaw społecznych. W: T. Rostowska, A. Lewandowska-Walter (red.), Matżeństwo i rodzicielstwo a zdrowie, 479-493. Torun: Wydawnictwo Adam Marszałek.

Filipczuk H. (1988), Wychowanie - dziecko w placówce opiekuńczo-wychowawczej. Warszawa: Nasza Księgarnia.

Gała A.E. (1992a), Inwentarz Rodzicielskich Technik Wychowawczych (IRTW), wersja dla młodzieży dorastającej. Niepublikowany podręcznik, Katedra Psychologii Wychowawczej i rodziny KUL.

Gała A.E. (1992b), Uwarunkowania wychowawcze dojrzałej moralności. Lublin: Oficyna Wydawnictwo Lew.

Gilman R., Huebner E. (2006), Characteristics of adolescents who report very high life satisfaction. Journal of Youth and Adolescence, 35, 293-301.

Goldbeck L., Schmitz T., Besier T., Herschbach P., Henrich G. (2007), Life satisfaction decreases during adolescence. Quality of Life Research, 16, 969-979.

Gosztyła T. (2010), Rodzinne uwarunkowania dojrzałej religijności młodzieży. Lublin: Wydawnictwo KUL. Grzesiuk L. (1979), Style komunikacji interpersonalnej. Warszawa: Wydawnictwo UW.

Harwas-Napierała B. (2014), Specyfika komunikacji interpersonalnej w rodzinie ujmowanej jako system. W: I. Janicka, H. Liberska (red.), Psychologia rodziny, 47-72. Warszawa: PWN.

Henry C.S. (1994), Family system characteristics, parental behaviors, and adolescent family life satisfaction. Family Relations, 43, 4, 447-455. 
Hofer J., Chasiotis A. (2003), Congruence of life goals and implicit motives as predictors of life satisfaction: Cross-cultural implications of a study of Zambian zale adolescents. Motivation and Emotion, 27, 251-272.

Hipwell A., Keenan K., Kasza K., Loeber R., Stouthamer-Loeber M., Bean T. (2008), Reciprocal influences between girls' conduct problems and depression, and parental punishment and warmth: A six year prospective analysis. Journal of Abnormal Child Psychology, 36, 5, 663-677.

Hoffman M.L. (1970), Conscience, personality, and socialization techniques. Human Development, 13, 90-126.

Hoffman M.L. (1975), Moral internalization, parental power, and the nature of parent-child interaction. Developmental Psychology, 11, 2, 228-239.

Hoffman M.L. (1994), Discipline and internalization. Developmental Psychology, 30, 1, 26-28.

Hoffman M.L. (2006), Empatia i rozwój moralny. Gdańsk: GWP.

Huebner E.S. (1991), Initial development of the student's life satisfaction scale. School Psychology International, 12, 3, 231-240.

Huebner E.S., Suldo S.M., Valois R.F. (2003), Psychometric properties of two brief measures of children's life satisfaction: The Students' Life Satisfaction Scale (SLSS) and the Brief Multidimensional Students' Life Satisfaction Scale (BMSLSS). W: Paper Prepared for the Indicators of Positive Development Conference, Child Trends, 1-33, https://www.childtrends.org/wp-content/uploads/2013/05/Child_Trends-2003_03_12_ PD_PDConfHSVP.pdf (dostęp: 18.11.2018).

Kuncewicz D., Sokołowska E. (2014), Narracje rodziców i ich dorosłych dzieci o wychowaniu. Roczniki Psychologiczne, 17, 4, 759-774.

Kurpiel D. (2015), Satysfakcja z życia a poczucie skuteczności i styl wychowania w percepcji matek młodzieży z niepełnosprawnością. Psychologia Rozwojowa, 20, 1, 75-89.

Levinson D.J. (1986), A conception of adult development. American Psychologist, 41, 3-13.

Marzec-Tarasińska A. (2016), Oddziaływania wychowawcze ojców a poglądy młodzieży na temat roli ojca w rodzinie. Wychowanie w Rodzinie, t. 13, 1, 257-276.

Marks J.L., Lam C.B., McHale S.M. (2009), Family patterns of gender role attitudes. Sex Roles, 61, 3-4, 221-234.

Nowak-Dziemianowicz M. (2013), Narracyjne możliwości pedagogiki a kryzys kultury i wychowania. Forum Oświatowe, 3, 50, 35-60.

Obuchowska I. (2007), Adolescencja. W: B. Harwas-Napierała, J. Trempała (red.), Psychologia rozwoju czlowieka, 163-178. Warszawa: PWN.

Palmer B., Donaldson C., Stough C. (2002), Emotional intelligence and life satisfaction. Personality and Individual Differences, 33, 7, 1091-1100.

Pankowska D. (2005), Wychowanie a role ptciowe. Gdańsk: GWP.

Patrick R.B., Gibbs J.C. (2012), Inductive discipline, parental expression of disappointed expectations, and moral identity in adolescence. Journal of Youth and Adolescence, 41, 8, 973-983.

Peterson C., Park N., Seligman M.E.P. (2005), Orientations to happiness and life satisfaction: The full life versus the empty life. Journal of Happiness Studies, 6, 1, 25-41.

Peterson C., Ruch W., Beermann U., Park N., Seligman M.E.P. (2007), Strengths of character, orientations to happiness, and life satisfaction. The Journal of Positive Psychology, 2, 3, 149-156.

Piko B.F. (2006), Satisfaction with life, psychosocial health and materialism among Hungarian youth. Journal of Health Psychology, 11, 6, 827-831.

Piotrowski K., Wojciechowska J., Ziółkowska B. (2014), Rozwój nastolatka. Późna faza dorastania. W: A.I. Brzezińska (red.), Niezbędnik Dobrego Nauczyciela, Seria I. Rozwój w okresie dziecińswa i dorastania, t. 6, 1-67. Warszawa: Instytut Badań Edukacyjnych.

Plopa M. (2004), Psychologia rodziny. Teoria i badania. Elblag: Wydawnictwo EUH-E.

Plopa M., Połomski P. (2010), Kwestionariusz Relacji Rodzinnych. Wersje dla młodzieży. Podręcznik. Warszawa: VIZJA PRESS \& IT.

Raczkowska J. (1998), Na tropach rodzicielskich niepowodzeń. Warszawa: IWZZ.

Rembierz M. (1998), Dom rodzinny jako „osobliwy szczegół” w świecie kulturowej bezdomności. Refleksje z filozofii człowieka. W: B. Dymara (red.), Dziecko w świecie rodziny - szkice o wychowaniu, 74-98. Kraków: Impuls.

Rembowski J. (1972), Więzi uczuciowe w rodzinie. Warszawa: PWN. 
Ryff C. (1989), Happiness is everything, or is it? Explorations on the meaning of psychological well-being. Journal of Personality and Social Psychology, 57, 6, 1069-1081.

Smykowski B. (2004), Wczesna dorosłość. Remedium, 2, 4-5.

Steca P., Caprara G.V., Tramontano C., Vecchio G.M., Roth E. (2009), Young adults' life satisfaction: The role of self-regulatory efficacy beliefs in managing affects and relationships across time and across cultures. Journal of Social and Clinical Psychology, 28, 7, 824-861.

Steinberg L., Morris A.S. (2001), Adolescent development. Journal of Cognitive Education and Psychology, 2, 1, 55-87.

Waldowski K. (2002), Realizacja zadań rozwojowych na porzełomie późnej adolescencji i wczesnej dorosłości. W: A. Brzezińka, K. Appelt, J. Wojciechowska (red.), Szanse i zagrożenia rozwoju w okresie dorostości, 55-84. Poznań: Wydawnictwo Humaniora.

Wnuk M., Zielonka D., Purandare B., Kaniewski A., Klimberg A., Ulatowska-Szostak E., Kaminiarz E. (2013), Przegląd koncepcji jakości życia w naukach społecznych Review of quality of life conceptions in social sciences, 48, 1, 10-16.

Wołpiuk-Ochocińska A., Marmola M. (2016), Relacje rodzinne a zadowolenie z życia u młodzieży na różnych etapach edukacji. Kwartalnik Naukowy Fides et Ratio, 1, 25, 149-165.

Zadworna-Cieślak M., Ogińska-Bulik N. (2011), Zachowania zdrowotne młodzieży. Uwarunkowania podmiotowe i rodzinne. Warszawa: Wydawnictwo Difin.

Ziemska M. (1979), Rodzina a osobowość. Warszawa: Wiedza Powszechna.

Ziółkowska B. (2005), Okres wczesnej dorosłości. Jak rozpoznać potencjał młodych dorosłych? W: A.I. Brzezińska (red.), Psychologiczne portrety człowieka. Praktyczna psychologia rozwojowa, 423-468. Gdańsk: GWP. 